\title{
SAMUEL JOHNSON'S GOUT
}

\author{
by
}

\section{J. P. W. ROGERS*}

\begin{abstract}
"What a man am I!", remarked Samuel Johnson a year before his death, "who have got the better of three diseases, the palsy, the gout, and the asthma, and can now enjoy the conversation of my friends, without the interruptions of weakness or pain!"' A lot has been written recently concerning Johnson's last days, and though his mental state has claimed most attention, there has been considerable discussion of his physical ailments. ${ }^{2}$ But gout has been largely ignored, perhaps because it cannot in any direct way have contributed to Johnson's death (the main point at issue in most such discussions). There is, however, a more substantive obstacle: namely, the difficulty we still have in deciding whether "gout" is an accurate description of the malady to which Johnson and his doctors gave this term. In this paper I shall attempt first a brief case history of Johnson's gout, real or alleged; and secondly conduct as much of a retrospective diagnosis as seems possible. Johnson's actual post mortem, carried out by James Wilson on 15 December 1784, is not of any obvious help here; but that is rather to be expected and need not deter this inquiry. Finally, I shall look at the light which this material throws on general attitudes in Johnson's age.
\end{abstract}

\section{I}

There is no real evidence of any onset of the illness before 1775, when Johnson was already in his mid-sixties. A few impersonal references can be culled from Johnson's writings, and just the slightest hint of some first-hand knowledge. In an 'Ode' published in the Gentleman's Magazine in 1747, this stanza occurs:

*Professor J. P. W. Rogers, MA, PhD, LittD., Department of English, University of Bristol, 3/5 Woodland Road, Bristol BS8 1TB.

An earlier version of this paper was delivered at the symposium on 'Samuel Johnson and Eighteenth-Century Medicine', held at the Wellcome Institute in February 1984. I should like to thank the organizers, Dr Roy Porter, Mr Robin Price, and Dr Isobel Grundy, for their kindness and help. The participants in the symposium made valuable comments from which $I$ have tried to profit in revising this paper.

'Sir John Hawkins, The life of Samuel Johnson, edited by B. H. Davis, London, Jonathan Cape, 1962, p. 255 .

${ }^{2}$ It would arrogate too much space to list all the contributions in this area: a representative item is B. S. Abeshouse, A medical history of Dr Samuel Johnson, Norwich, NY, 1965. 


\title{
J. P. W. Rogers \\ Unhappy! whom to beds of pain \\ Arthritick tyranny consigns \\ Whom smiling nature courts in vain \\ Tho' rapture sings, and beauty shines.
}

The note to this passage, on its original printing, reads, "The Author being ill of the Gout". ${ }^{3}$ Boswell puzzled over this note in his Life, on the grounds that Johnson "was not attacked with that distemper till at a very late period of his life." His answer is characteristic, in that it looks slightly strained but has some force in it: ("May not this ... be a poetical fiction? Why not a poet suppose himself to have the gout, as well as suppose himself to be in love?"4) The idea that "arthritick" is a kind of generalized term of poetic diction has an attractive side, rather along the lines of "Feeble of foot, and rheumatic of shoulder" in E. E. Bowen's 'Forty years on'. Later in this paper we shall return to the gout/arthritis confusion: it is worth noting at this point that all the early uses of the epithet arthritic in $O E D$ relate unambiguously to gout. A representative citation in this entry is one from Chambers' Cyclopedia (ed. 1752), "Arthritic Waters are good against the gout".

Johnson's own ideas about gout may be seen from the relevant definitions in his own Dictionary (1755). The principal heading for gout contains this gloss: "the arthritis; a periodical disease attended with great pain", followed by quotations from Dr John Arbuthnot on diet, Cymbeline, and Dryden's translation of Juvenal. The adjective gouty has citations from Arbuthnot and Dryden again, plus this interesting sentence from Graunt's Bills of Mortality: "There dies not above one of a thousand of the gout, although I believe that more die gouty." More revealing in some respects is the entry for arthritis, that is, "Any distemper that affects the joints, but the gout most particularly". The source for this statement is given as Quin., that is the medical writer John Quincy. Arthritick/arthritical is defined first as gouty, and second, in a more etymological fashion, as relating to joints. Again Arbuthnot, a favourite source, is drawn on.

We know that by 1773 Johnson was taking some interest in the treatment of gout, as witnessed by a conversation in Skye during his Hebridean jaunt. Boswell reports this conversation on 14 September:

\begin{abstract}
At supper, Lady McLeod mentioned Dr Cadogan's book on the gout. Mr Johnson said, “ 'Tis a good book in general, but a foolish one in particulars. 'Tis good in general, as recommending temperance and cheerfulness. 'Tis only Dr Cheyne's book told in a new way. And there should come out such a book every thirty years, dressed in the mode of the times. 'Tis foolish, as it says, the gout is not hereditary, and one fit of the gout when gone is like a fever when gone."
\end{abstract}

The conversation veers off on to wider aspects of Cadogan's tract, and indeed culminates in the famous comment that man is no more naturally good than a wolf. It

${ }^{3}$ D. Nichol Smith and E. L. McAdam (editors), The poems of Samuel Johnson, 2nd ed., Oxford University Press, 1974, p. 102.

'James Boswell, The life of Samuel Johnson, edited by G. B. Hill, revised by L. F. Powell, Oxford University Press, 1934-50, vol. 1, p. 179.

John Graunt (1620-74), pioneer statistician.

${ }^{6} \mathrm{~F}$. A. Pottle and C. H. Bennett (editors), Boswell's journal of a tour in the Hebrides, London, Heinemann, 1936, pp. 168-169. 
is clear that Johnson was fully familiar with William Cadogan's Dissertation on the gout and on all chronic diseases (1771). But this is only to be expected, in view of the popularity of this work, as of George Cheyne's much reprinted Observations on the gout (1720). Cadogan was even less of an original clinical researcher than Cheyne, and educated readers - let alone omnivorous lexicographers - would have come across the work regardless of any personal interest in the subject. Besides, Johnson's lifelong friend David Garrick had consulted Cadogan for his own complaint, diagnosed as gout, and had subjected himself to a regime prescribed by the physician. ${ }^{7}$ This circumstance in itself would be quite sufficient to explain Johnson's awareness of the tract. ${ }^{8}$

As already stated, then, we must wait until 1775 before we have any concrete evidence regarding Johnson's own sufferings. On 29 August of that year he writes to Mrs Thrale, "This sorry foot! and this sorry Doctor Laurence who says it is the Gout! But he thinks every thing the gout, and so I will try not to believe him."' Johnson continues by supposing that Mrs Thrale, who was to take him to Brighton, will plunge his lame foot "into the sea", a reminder that this was the very decade when sea-bathing was at its very height of popularity as a cure-all. The reference is to $\mathrm{Dr}$ Thomas Lawrence (1711-83), a friend as well as personal physician to Johnson and one described by him as among the best men he had known. It is apparent that the bout, however painful, was not severe enough to warrant a mention in a longish letter to Boswell two days earlier, or a short one just a single day later.

We can be more precise with regard to an attack in the following year. Chronologically, the first reference is in a letter to Henry Thrale on 3 June 1776: "The lameness, of which I made mention in one of my notes, has improved to a very serious and troublesome fit of the gout. I creep about and hang by both hands .... I enjoy all the dignity of lameness. I receive ladies and dismiss them sitting. Painful pre-eminence." There are several references to the progress of this illness in following letters, for example one to Mrs Thrale on 4 June ("I can creep to the end of the court, and climb into a coach though perhaps not very easily"); on 5 June ("I have never had any overpowering pain, nor been kept more awake than is usual to me; but I am a very poor creeper upon the earth, catching at any things with my hands to spare my feet"); and 6 June ("This gout had a little depressed me, not that I have suffered any great pain, I have been teized rather than tortured; but the tediousness and the imbecility have been unpleasant. However I now recover enough strength and do not yet despair of kicking the Moon" - but another twinge struck before he completed the missive). Progress remained slow for the next couple of weeks: by 23 June, Johnson was able to write to Dr John Taylor, "The Gout is now grown

${ }^{7}$ D. M. Little and G. M. Kahrl (editors), The letters of David Garrick, London, Oxford University Press, 1963 , vol. 3, p. 739.

${ }^{8} \mathrm{An}$ interesting exchange is reported later by Bennet Langton, concerning the occasion when Johnson met Cadogan at Warley Camp in the summer of 1778. Johnson complained of ill health: Cadogan asked him, "what plan he followed with a view of better health - he answered very impatiently 'I pursue no plan!' Dr Cadogan then said ...'surely it is eligible for you to consider of any Regimen or plan that might have a chance for restor'd health'." C. N. Fifer (editor), The correspondence of James Boswell with certain members of the Club, London, Heinemann, 1976, p. 32.

${ }^{9} \mathrm{R}$. W. Chapman (editor), The letters of Samuel Johnson, Oxford University Press, 1952, vol. 2, p. 84. Hereinafter cited as Letters. 


\section{J. P. W. Rogers}

tolerable; I can go up stairs pretty well, but am yet aukward in coming down." He added the thought, "I hope you persevere in drinking. My opinion is that I have drank too little, and therefore have the gout, for it is of my own acquisition, for neither my father had it nor my mother." 10 In an age of medical understanding which could generally observe hereditary ailments like the Dedlock gout only when members of a family reported their parents' clinical history, this is a useful first-hand testimony. It also provides a nice contrast to Horace Walpole's reflections on his own inherited (but, he considered, unearned) distresses. ${ }^{11}$

It was not until 6 July that Johnson sent Boswell in Edinburgh his first dispatch on the topic: "It vexes me to tell you, that on the evening of the 29th of May I was seized by the gout, and am not quite well. The pain has not been violent, but the weakness, and tenderness were very troublesome, and what is said to be very uncommon, it has not alleviated my other disorders. Make use of youth and health while you have them ...." The belief that gout would drive out other ailments we shall encounter again - it is all but universal in symptomatologies, amateur or professional, in this period. Johnson writes as though confident that the bout is near an end, and the topic disappears from his correspondence at this point. Attention shifts to the declining health of his troublesome house-guest Mrs Williams and other matters. He was in Brighton again in October and went into the sea, though writing to Dr Robert Levet that "I know not that it does me any good." 12 Whether this comment applies to gout or other ailments, I do not know. All in all, the bout in $\mathbf{1 7 7 6}$ was the most prolonged to date, but not totally incapacitating. William Jones, the jurist and linguistician, had written to Viscount Althorp on 15 June that Johnson bore his illness "with unusual good temper". ${ }^{13}$ It is worth adding that Mrs Thrale began her most detailed record of her life on 15 September, with the inception of Thraliana: had she begun only a matter of weeks earlier, we might have a fuller record of this bout. The earliest relevant entry in Thraliana concerns a remark by Johnson in December 1777, when he observed that gout "seldom takes the Fort by a Coup de main, but turning the Siege into a Blockade - obliges it to surrender at Discretion" (i.e. unconditionally). ${ }^{14}$

As it is, the story moves on three years, to a less serious episode in 1779 . Johnson reports this to Dr Taylor on 19 October: "I have had a little catch of the gout; as I have had no great opinions of the benefits which it is supposed to convey, I made haste to be easy, and drive it after two days." This was a heretical view, directly opposed to Mrs Thrale's, but one that Johnson was not able to sustain under the increasing pressure of his last years. In the meanwhile the subject seems to have

\footnotetext{
${ }^{10}$ Letters, vol. 3, pp. 138-140, 144-145.

${ }^{11}$ W. S. Lewis et al. (editors), The correspondence of Horace Walpole, New Haven, Conn., Yale University Press, 1937-83, vol. 9, p. 291. Walpole's temperate way of life could be abundantly documented: for a single example, see ibid., vol. 24, p. 286ff. Boswell discussed gout with Horace Walpole in 1788, as well as talking about Johnson: G. Scott and F. A. Pottle (editors), Private papers from Malahide Castle, Mount Vernon, NY, privately printed, 1928-34, vol. 17, p. 102. Boswell's great friend, Edmond Malone, puzzled over the molestations of a "gout" which was neither hereditary nor "earned" by intemperance: A. Tillotson (editor), The Percy letters, Baton Rouge, Louisiana State University Press, 1944, vol. 1 .

${ }^{12}$ Letters, vol. 2, pp. 147, 151.

${ }^{13} \mathrm{G}$. Cannon (editor), The letters of Sir William Jones, Oxford University Press, 1970, vol. 1, p. 219.

${ }^{14}$ Katharine C. Balderston (editor), Thraliana, 2nd ed., Oxford University Press, 1951, vol. 1, p. 197.
} 


\section{Samuel Johnson's gout}

dropped from immediate attention, and nothing directly relevant emerges until he raises the possibly beneficial effects of gout in writing an account in Latin of his compounded ailments: this was addressed to Dr Lawrence on 13 March 1782, containing the observation, "Ego olim, cum podagra maxime saeviit, et pede et pectore simul laboravi."15

But in Mrs Thrale's view the crucial moment had occurred in the interim, during a visit to Sunninghill Park, Berkshire, in late July 1781. The incident remains a little obscure: we know from Fanny Burney that Johnson went down with the Thrales to the home of Jeremiah Crutchley. Then, long after Johnson's death, we find Mrs Thrale writing on 19 December 1794, "I am persuaded Dr Johnson died of repelled Gout - You may remember the trick he played at Sunninghill putting his feet in cold water. He never was well after." ${ }^{16}$ Crude and indeed in modern terms unintelligible as the diagnosis may be, it is well worth noting that this testimony comes from Mrs Thrale, who saw more of Johnson day by day throughout the year than anyone else who has left a record. In any account of Johnson's medical history, it should be kept in mind. Whilst it would be going beyond the evidence to locate this date as marking the beginning of Johnson's final decline, we are in no position to question Mrs Thrale's judgement that the trip to Berkshire, if not the "trick" of bathing his feet, constituted a turning-point in his general health.

The most fully reported case is the last, that occurring in the autumn of 1783 . By this time, Johnson's general health was falling rapidly away, and the complication of disorders mentioned at the start of this paper made itself felt. Among these the best-known episode is Johnson's stroke, suffered in June of this year; in addition, longer-standing conditions (asthma and dropsy, or rather pulmonary heart failure and emphysema), were growing in their severity. In August, a sarcocele was diagnosed and surgery contemplated by Cruikshank and Percival Pott; drainage provided only temporary respite. In the midst of these troubles Johnson told Bennet Langton on 24 September of yet another reverse: "The Gout has within these four days come upon me with a violence, which I never experienced before. It has made me helpless as an infant. It is no great evil in itself but [ ] delays the Chirurgeon" (that is, surgery for his sarcocele). On 30 September, he repeated the information to Boswell: "Besides my constant and radical disease, I have been for these ten days much harassed with the gout, but that has now remitted." The same day, he told Queeney Thrale that the fit had increased to a point where "I could not without many expedients and repeated efforts raise myself in bed; nor without much pain and difficulty by the help of two sticks convey myself to a chair. Dr Brocklesby allowed

\footnotetext{
${ }^{15}$ Letters, vol. 2, pp. 309, 465. The orthodox view of the "benefits" of gout is expressed by Horace Walpole to William Cole: "As the gout certainly carries off other complaints, . . it is rather a remedy than a disease." Correspondence, op. cit., note 11 above, vol. 1, p. 366.

${ }^{16}$ The Marquis of Lansdowne (editor), The Queeney letters, London, Cassell, 1934, p. 254; cf. [Charlotte Barrett (editor)], Diary and letters of Madame d'Arblay, London, Henry Colburn, 1842, vol. 2, p. 77. This can hardly be the episode referred to by Fanny Burney in her old age, which she assigns to a period "near the middle of his life, and in the fullest force of his noble faculties" (Memoirs of Doctor Burney, London, Moxon, 1832, vol. 2, pp. 207-208). There, Fanny describes a severe fit of gout which caused Johnson to plunge his leg in a pail of cold water, "a feat of intrepid ignorance ...for the gout, of which he chose to get rid of in so succinct a manner - a feat in which he often exalted - might have carried off many of the direful obstructions, and asthmatic seizures and sufferings, of which his latter years were wretchedly the martyrs."
} 


\section{J. P. W. Rogers}

large doses of opium which naturally eased the pain. It then withdrew in part from the right foot, but fell furiously on the left. But one foot was a great acquisition. I now walk alone." 17 To make matters worse, if that were possible, a bad toothache required an extraction.

One of the out-of-town physicians whom Johnson had consulted about his various afflictions was John Mudge of Plymouth. Johnson sent Mrs Thrale a report of Mudge's views on 6 October: "To the Gout my mind is reconciled by another letter from Mr Mudge, in which he vehemently urges the excision [of the sarcocele], but tells me that the gout will secure me from every thing paralytick, if this be true I am ready to say to the arthritick pains - Deh! venite ogni di, durate un anno." His former rejection of this easy consolation was by now much qualified, perhaps as an outcome of his terrifying stroke in the summer. Further correspondence in subsequent days naturally concentrated mainly on the possibility of surgery for the sarcocele, but contained brief reports on the complicating factor of gout. Thus, Johnson writes to Mrs Thrale on 9 October, "The Gout, which was for a while very oppressive, is now daily remitting, so that I walk easily enough without shoes between two rooms on the same floor." In most eighteenth-century town houses, including Johnson's birthplace and his home in Gough Square, rooms seldom were on the same floor; but Bolt Court may have been just a little better in this respect. A similar message went to Dr Taylor on 20 October, with a repetition of Mudge's hopeful view that gout would be "a security against the palsy; and indeed I recollect none that ever had both." On 23 October, Johnson told William Bowles "The Gout has treated me with more severity than any former time, it however never climbed higher than my ankles, in which it has now left a weakness, as well as tenderness in my feet, but when I do not walk or stand too long I have no longer any pain." A final reference comes in a letter to Mrs Thrale on 1 November, which contains the passage: "The Gout too is almost well in spite of all the luxury to which my Friends have tempted me by a succession of Pheasants, Partridges, and other delicacies. But Nature has got the better. I hope to walk to Church tomorrow." ${ }^{18}$ Conventional wisdom proscribed rich diet during an attack of gout, and not without medical reason.

In this review I have omitted the most significant statement, which opens Johnson's letter to Mudge on 9 October: "By representing the Gout as an antagonist to the palsy, You have said enough to make it welcome. This is not strictly the first fit, but I hope it is as good as the first, for it is the second that ever confined me, and the first was ten years ago, much less fierce and fiery than this." ${ }^{19}$ This is Johnson's only retrospective account, and since it was made in privacy to a doctor there would be small reason to falsify the facts - indeed, a strong incentive to tell the strict truth. The passage shows that Johnson considered his bout in 1776 (just possibly linked with that in 1775) to be the first serious onset of his illness, sufficient, that is, to confine him. Thereafter, Johnson passes to the main object of his concern, that is the sarcocele. Again, gout as the lesser and non-mortal condition would be unlikely to prompt inventions on Johnson's part.

\footnotetext{
${ }^{17}$ Letters, vol. 3, pp. 77-78.

${ }^{18}$ Ibid., pp. 79-95.

${ }^{19}$ Ibid., p. 86.
} 


\section{Samuel Johnson's gout}

This is almost the last we hear of the subject. One additional reference is supplied by his biographer Hawkins, placed around the "middle of 1784", that is, some six months before Johnson's death: "He had recovered from the paralytic stroke of the last year, to such a degree, that, saving a little difficulty in his articulation, he had no remains of it: he had also undergone a slight fit of the gout, and conquered an oppression on his lungs, so as to be able, as he himself told me, to run up the whole staircase of the Royal Academy, on the day of the annual dinner there. In short, to such a degree of health was he restored, that he forgot all his complaints ...." ${ }^{20}$ It is evident that the "slight fit" mentioned here was the same attack of gout we have just witnessed in the autumn of 1783. The dinner in question took place on 24 April 1784, when (as he told Mrs Thrale) "I admired nothing but myself. I went up all the stairs to the pictures without stopping to rest or breathe, 'In all the madness of superfluous health." "So strong an impression did this renewed vigour make on him that as late as 16 August he was writing to Dr Richard Brocklesby, who had accompanied him to the Academy, that he did not "despair of another race upon the Stairs" of this august institution. ${ }^{21}$

By this time, Johnson was at the point of breaking with Mrs Thrale, and we lack her detailed view of the final months. She had decided a long time before that his medical troubles all went back to "repressed gout": there is a note in Thraliana on 17 December 1781, "my Fear is lest he should grow paralytick, there are really some Symptoms already discoverable I think, about the Mouth particularly; he will drive the Gout away so when it comes, and it must go somewhere."22 Her forebodings regarding a stroke perhaps go back to her first husband's fatal apoplexy eight months earlier. It is possible that her phrasing suggests recurrent minor attacks of gout which Johnson himself did not report: but his testimony to Mudge in 1783 leaves no doubt that we have a record of these bouts he himself regarded as seriously disabling.

For the rest of her life, even after Mrs Thrale acquired a more severe case to observe at first hand in the shape of her second husband Piozzi, she continued to hold to her opinions on Johnson's disorder. We have already seen her comment in 1794, and there are other occasional references. One that illuminates general attitudes dates from 1806: "Mr Piozzi has had no regular fit of the Gout this whole year and he begins to feel alarmed at it - such a thing has not befallen him for twelve or fifteen seasons and I tell him he wants his customary amusements; you know Doctor Johnson said chronical illnesses served sick men for a pastime." More casual is the comment Mrs Piozzi made when her second husband had his earliest bad attack: "I did not know (like Doctor Johnson and the Tart) that Gout could have been so bad." Piozzi's condition, incidentally, has been defined in modern times as "gouty arteriosclerosis", which seems to hedge as nakedly as any eighteenth-century diagnosis. ${ }^{23}$

\footnotetext{
${ }^{20}$ Hawkins, op. cit., note 1 above, p. 259.

${ }^{21}$ Letters, vol. 3, pp. 159, 199. Richard Brocklesby (1722-97), neighbour, friend, and physician to Johnson.

${ }^{22}$ Thraliana, op. cit., note 14 above, vol. 1, p. 521; see also the reference to Johnson's "repelled gout" having "fallen on his lungs", ibid., vol. 1, p. 528.

${ }^{23}$ Queeney letters, op. cit., note 16 above, pp. 258-259; J.L. Clifford, Hester Lynch Piozzi (Mrs Thrale), 2nd ed., Oxford University Press, 1968, p. 369. For Mrs Piozzi's continued belief that "Gout is a pledge of long life", and that "nothing runs on like a life subject to one chronic or regular complaint [like gout]", see
} 


\section{J. P. W. Rogers}

Johnson died on 13 December 1784. Two days later, James Wilson conducted a post-mortem examination, which is preserved in the library of the Royal College of Physicians. In accustomed manner, this looks for the immediate causes of death and concentrates on the main organs of the chest and abdomen. There is no sort of comment on the extremities or indeed any part of the body outside the trunk.

\section{II}

The facts set out thus far suggest a simple enough history. What Johnson and others regarded as a case of gout first presented itself in 1775 , when he was on the eve of his sixty-sixth birthday. A more serious attack, involving prolonged confinement and treatment, occurred in the following year. Thereafter, the condition appears to have remained comparatively quiet, if not totally dormant. According to Mrs Thrale, Johnson's general health - possibly, but not certainly, including his "gout" - took a perceptible turn for the worse around the summer of 1781 . Then in 1783, when he was beset by a number of disorders, a bad attack struck him and necessitated further confinement: as in 1776, the bout appears to have lasted something like three weeks, with its severest effects apparent early on and then gradually declining into a state of mere "tenderness". In all cases the feet alone were affected. Johnson was treated by his general physicians, that is Lawrence in the 1770s and then William Heberden and Richard Brocklesby. He also took advice from John Mudge by correspondence.

These circumstances are not sufficient to build up a totally definitive view of the case. It is well known that eighteenth-century medicine had made little headway in differentiating between gout proper, as now understood, and various forms of arthritic disease. Some medical historians would be inclined to speculate that Johnson's condition was actually of this latter order, something that has been proposed in the case of Horace Walpole's longer-lasting and better-documented illness. There are certainly suspicious factors which make this a distinct possibility in respect of Johnson also.

Clearly, Johnson, as his Dictionary definitions show, had at his hands no sharper tools of diagnostic terminology than his contemporaries at large. Nothing is commoner in the era than a remark such as this, made by Samuel Crisp, the dramatist and mentor of Fanny Burney: "My [ankles] feel very Rheumatick or Gouty - I don't know which." Horace Walpole's wry observation that all chronic distempers "are or ought to be gout" (all else being deviations) reflects the serious difficulties experienced in diagnosis. ${ }^{24}$ It is true that Johnson himself had more medical

O. G. Knapp (editor), The intimate letters of Hester Piozzi and Penelope Pennington, London, John Lane, 1914, pp. 193, 286.

${ }^{24}$ W. H. Hutton, Burford papers, London, Constable, 1905, p. 76; Walpole, Correspondence, op. cit., note 11 above, vol. 25, p. 652; and see ibid., vol. 10, p. 263. For a similar uncertainty in Mrs Siddons regarding her husband's ailment, see Douglas Goldring, Regency portrait painter. The life of Sir Thomas Lawrence PRA, London, Macdonald, 1951, p. 148. Diagnosis was made the harder because of the ignorance of the existence of toxins in the peripheral nerves, which led contemporaries to attribute all pain in the extremities to a condition of the joints themselves. This happened in the case of George III and his sons. See Ida Macalpine and Richard Hunter, George III and the mad-business, London, Allen Lane, 1969, esp. pp. 230, 251. 


\section{Samuel Johnson's gout}

knowledge than most laymen; his early lives of Sydenham (1742) and Boerhaave (1739) brought him familiarity with great physicians who experienced gout in their own person. But all this means is that he shared in a general state of vagueness.

Let us consider some of the most suspicious factors. One contra-indication is provided by the late onset of the ailment. It would be normal for true gout to make itself felt at least thirty years earlier than the record supplies in Johnson's instance. It is possible that the patient suffered earlier minor onslaughts, not regarded as identifiable as gout: but this would not be a characteristic pattern. A more likely explanation would depend on the relative dearth of information for Johnson's earlier years, in the decades before Boswell, Mrs Thrale and Fanny Burney chronicled his every doing. Nevertheless, the doubt remains, and it is a strong one.

Earlier on, we noted Johnson's comment to the effect that his gout was "of [his] own acquisition", since neither of his parents suffered from it. In the case of his mother, this is of very little significance, since the ailment remains distinctly rare among women - though, by eighteenth-century definitions, gout was not so uncommon in the female population. There is, of course, a hereditary predisposition involved in the illness, and if Michael Johnson had suffered from a well-attested case, that would be a small positive sign. All we know is that Johnson's maternal uncle Joseph Ford is said to have died from a painful mortification of the feet following two months of incapacity from gout - but yet again one must suspect the nomenclature. ${ }^{25}$

It has been suggested that the absence of any reference in the post mortem to true gout symptoms, specifically tophi, may be significant. I do not regard this as a strong indication either way. Autopsies were commonly directed to the leading agencies of mortality, and tended to concentrate on the vital organs. Wilson does not mention any sort of swelling or disorder of the joints, let alone deposits of the characteristic sort; indeed, he does not mention the limbs at all - but this was usual. Similarly, William Heberden discusses Johnson's asthma, paralysis, and sarcocele, but makes no mention of his gout. ${ }^{26}$ One might add that Wilson specifically states that the cranium was not opened, and, of course, no kind of examination of the brain was undertaken - even though Johnson's history of cerebral damage was perfectly well known. Consequently, it would be rash to argue from omissions in this particular respect.

Johnson's descriptions of his illness are not detailed enough to settle the dubious matters. The duration of each bout, and the interval elapsing between them, might be thought consistent with true gout; and since only the extremities were involved there is nothing in that aspect of the record which would preclude a positive diagnosis. On balance, one would have to conclude that it remains possible that Johnson was a true sufferer from gout, with the onset for some reason either delayed or not reported. But a form of degenerative arthritis is equally consistent with the known facts, and perhaps rather more likely in the light of all the circumstances.

${ }^{25}$ A. L. Reade, Johnsonian gleanings, New York, Octagon Books, 1968, vol. 3, p. 142.

${ }^{26}$ Entries from Index historiae morborum (1802), preserved in the library of the Royal College of Physicians of London and reproduced in the exhibition catalogue, Dr Samuel Johnson and eighteenth-century medicine, London, Wellcome Institute for the History of Medicine, 1984, pp. 26-27. 


\section{J. P. W. Rogers}

Finally, some brief consideration of what the story of Johnson's gout, real or supposed, tells us about attitudes to the illness at the end of the eighteenth century. Along the way we have encountered a number of highly revelatory comments, some of which I shall now pick up. For example, the Dictionary's citation of the Bills of Mortality, "There dies not above one in a thousand of the gout." The figures listed for 1774 actually name fifty-four out of 21,000 deaths in London as attributable to gout, which is more like 2.5 per thousand-still implausibly high. ${ }^{27}$ Quite a number of individuals are stated in standard sources to have died from the ailment, including the actors Betterton and Barry, the composer Boyce, the writer James Ralph, the mother of John Wesley, and (in some accounts) the disappointing natural son of Lord Chesterfield, Philip Stanhope - here an alternative and marginally more promising diagnosis is tuberculosis of the joints. It should be mentioned that one informant attributes the death of the elder Pitt, perhaps the most celebrated "gout" victim of the age, to mismanagement of this condition on the part of no less a figure than William Hunter - but the evidence for this is not apparent. Perhaps the most striking mortality is fictional: the Duchess of Devonshire's novel The sylph (1779) has a young heiress plunging a painful ankle in cold water and then dying so rapidly from gout of the head and stomach that she has no time to make a will. ${ }^{28}$

Turning to treatment and management, we have already noted Johnson's interest in the popular tract by William Cadogan. Not only a close friend, Garrick, but a more distant acquaintance in the Club, Edward Gibbon, would have brought this work to Johnson's attention. On 27 October 1784, two months before Johnson died, Gibbon wrote to his stepmother that he was successfully combating the gout which had first attacked him in 1774 (at the more plausible age of thirty-seven). He writes, "Of $\mathrm{Dr}$ Cadogan's three rules I can observe two [,] a temperate diet and an easy mind" activity was the remaining rule which Cadogan had prescribed to combat his triple scourges of indolence, intemperance, and vexation. Gibbon's references to his "old Enemy" are scattered over twenty years, and build up a more convincing case history than is true of Johnson; one might add that among those Gibbon was able to consult in Lausanne was the celebrated Samuel-Auguste-André-David Tissot. ${ }^{29}$

Needless to add, Johnson was familiar with many other people who had, or thought they had, gout. The list begins with his early mentor Gilbert Walmesley; it includes another Lichfield celebrity, Erasmus Darwin, who took a rather different view from Johnson and thought that his abstention from wine and beer averted any serious attack from his mid-forties. Others in Johnson's extended acquaintance who

\footnotetext{
${ }^{27}$ Quoted by John Hampden, An eighteenth-century journal, London, Macmillan, 1940, p. 126. It has been pointed out to me that gout without treatment can lead indirectly to a high mortality rate from kidney and artery diseases, but most of these connexions were dimly, if at all, perceived in the period, and it seems unlikely that the death statistics would trace such mortalities back to "gout" eo nomine.

${ }^{28}$ Alexander Carlyle, Anecdotes and characters, edited by J. Kinsley, London, Oxford University Press, 1973, p. 176; Arthur Calder-Marshall, The two duchesses, London, Hutchinson, 1978, p. 38. Other non-fatal cases of gout, real or alleged include the singer Michael Kelly and Walpole's friend Horace Mann. Johnson once met the American physician Benjamin Rush, who later wrote Observations on the nature and cure of the gout (1798).

${ }^{29} \mathrm{~J}$. E. Norton (editor), The letters of Edward Gibbon, London, Cassell, 1956, vol. 3, pp. $18,266$.
} 


\section{Samuel Johnson's gout}

may be mentioned are Sir Joseph Banks, the actor James Quin, the painter Francis Hayman, and the jurist Sir William Blackstone. Other prominent contemporaries were Robert Clive, the Duke of Bedford, Lord Macartney, Admiral Rodney, Bishop Berkeley (a strong believer in the curative properties of gout as regards other ailments), and the Earl of Bristol, another of those asserted in some quarters to have died from gout. Here there would be a possible hereditary factor, since Lord Bristol was the son of Lord Hervey (Pope's "Sporus") and Mary Lepell; his mother is reported by Allan Ramsay to have suffered so badly from gout in later years that she could move neither hand nor foot. ${ }^{30}$ The most interesting case in this group is that of the publisher Robert Dodsley, a close friend of Johnson. Acute symptoms were apparent by his mid-thirties, involving a confinement lasting seventeen months and the adoption of "crutches and cloath shoes". Dodsley actually wrote a poem, Pain and patience, (1742) on the topic. After turning sixty, Dodsley could scarcely walk at all, and predictably his death at the age of sixty-four has been attributed to this cause. $^{31}$

Johnson followed an orthodox regimen, and accepted conventional wisdom in abjuring rich diet whenever possible during his periods of confinement. ${ }^{32}$ It goes almost without saying that much weirder modes of treatment were on offer, ranging from coffee (contra-indicated, according to modern notions), and milk and turnips as tried by Horace Walpole's friend John Chute, to a variety of quack remedies. It would be a distraction to list many of the latter, but it is hard to resist brief mention of Cagliostro's technique. This involved bathing the affected foot in water and draining off mercury; this worked until the charlatan was caught surreptitiously introducing a spoonful of mercury into the water. ${ }^{33}$

Johnson's own attitude to his sufferings is more revelatory of the man than the age, though it does chime in with some contemporary comment. Dodsley, for example, wrote, in almost Johnsonian accents, "We must submit to these things, they are annexed to humanity, and serve a very good purpose in weaning us from the world." ${ }^{34}$ Many people thought gout a suitable cross for those of advancing years to bear, especially if it took the "regular" and not "flying" form, that is broadly speaking if it remained in the limbs and did not spread (as it was thought to do) to the stomach and spleen. But no one else is able quite to match Johnson's fortitude and wry self-deprecation. There was a certain dignity in the disease, as it was then conceived: Johnson accepts the absurd "pre-eminence" along with the pain. A few years later, George Sand's grandmother was to instil in the young girl the lesson that "if you had gout, you walked anyway, without grimacing, your breeding made you

\footnotetext{
${ }^{30}$ Alastair Smart, The life and art of Allan Ramsay, London, Routledge \& Kegan Paul, 1952, p. 128. Walpole reported the death of a brother in 1775 , and said that "he was born to the gout from his mother's family, but starved himself to keep it off. This brought on paralytick strokes, which have dispatched him." Walpole, Correspondence, op. cit, note 11 above, vol. 24, p. 85. 300 .

${ }^{31}$ Ralph Straus, Robert Dodsley: poet, publisher and playwright, London, John Lane, 1910, pp. 79, 145 ,

${ }^{32}$ Hume once congratulated himself on not falling victim to "any bad gout, as is ordinary", despite the indulgence of a "ravenous" appetite. E. C. Mossner, The life of David Hume, 2 nd ed., Oxford University Press, 1980, p. 68.

${ }^{33}$ Vincent Cronin, Catherine, Empress of all the Russians, London, Collins, 1978, p. 229.

${ }^{34}$ Straus, op. cit., note 31 above, p. 300.
} 


\section{J. P. W. Rogers}

hide your pain". ${ }^{35}$ Johnson was too sensible to make a virtue of his sufferings, too suspicious of easy stoical answers to glory in insensibility ${ }^{36}$ but he did cope manfully with his illness, whatever it was. What he feared was death, and especially the sudden coup de foudre such as the one which removed Henry Thrale. Where the illnesses of the Thrale children seemed arbitrary and cruel in their irresistible effect, gout at least appeared to the eighteenth-century mind a gentlemanly adversary who played according to the rules. In a world of tragic contingency, there was a logic and Leibnitzian justice in gout which exempted it from the category of illness at large.

${ }^{35}$ George Sand, My life, trans. by D. Hofstadter, London, Gollancz, 1979, p. 7. One recalls, too, the Duchess of Northumberland's phrase concerning "all the deliberation of gout" (her own); see J. Greig (editor), The diaries of a duchess, London, Hodder \& Stoughton, 1926, p. 211.

${ }^{38}$ Compare Lady Craven's view that "the gout may be said to be a beacon on the rock of luxury to warn against it: during distress, vows of repentance are made; during the intervals, these vows are forgotten". A. M. Broadley and Lewis Melville, The beautiful Lady Craven, London, John Lane, 1914, vol. 2, pp. 177-178. 